\title{
Buprenorphine-Induced Antinociception Is Mediated by $\mu$-Opioid Receptors and Compromised by Concomitant Activation of Opioid Receptor-Like Receptors
}

\author{
Kabirullah Lutfy, ${ }^{1}$ Shoshana Eitan, ${ }^{1}$ Camron D. Bryant, ${ }^{1}$ Yu C. Yang, ${ }^{1}$ Nazli Saliminejad, ${ }^{1}$ Wendy Walwyn, ${ }^{1}$ \\ Brigitte L. Kieffer, ${ }^{2}$ Hiroshi Takeshima, ${ }^{3}$ F. Ivy Carroll, ${ }^{4}$ Nigel T. Maidment, ${ }^{1}$ and Christopher J. Evans ${ }^{1}$ \\ ${ }^{1}$ Department of Psychiatry and Biobehavioral Sciences, University of California, Los Angeles, Neuropsychiatric Institute, Los Angeles, California 90024, \\ ${ }^{2}$ Institut de Genetique et de Biologie Moleculaire et Cellulaire, Centre National de la Recherche Scientifique-Institut National de la Santé et de la Recherche \\ Médicale-Université Louis Pasteur, 67404 Illkirch Cedex, France, ${ }^{3}$ Department of Biochemistry, Tohoku Graduate School of Medicine, Sendai, Miyagi 980- \\ 8575, Japan, and ${ }^{4}$ Chemistry and Life Sciences, Research Triangle Institute, Research Triangle Park, North Carolina 27709-2194
}

Buprenorphine is a mixed opioid receptor agonist-antagonist used clinically for maintenance therapy in opiate addicts and pain management. Dose-response curves for buprenorphine-induced antinociception display ceiling effects or are bell shaped, which have been attributed to the partial agonist activity of buprenorphine at opioid receptors. Recently, buprenorphine has been shown to activate opioid receptor-like (ORL-1) receptors, also known as OP4 receptors. Here we demonstrate that buprenorphine, but not morphine, activates mitogen-activated protein kinase and Akt via ORL-1 receptors. Because the ORL-1 receptor agonist orphanin FQ/nociceptin blocks opioid-induced antinociception, we tested the hypothesis that buprenorphine-induced antinociception might be compromised by concomitant activation of ORL-1 receptors. In support of this hypothesis, the antinociceptive effect of buprenorphine, but not morphine, was markedly enhanced in mice lacking ORL-1 receptors using the tail-flick assay. Additional support for a modulatory role for ORL-1 receptors in buprenorphine-induced antinociception was that coadministration of J-113397, an ORL-1 receptor antagonist, enhanced the antinociceptive efficacy of buprenorphine in wild-type mice but not in mice lacking ORL-1 receptors. The ORL-1 antagonist also eliminated the bell-shaped dose-response curve for buprenorphine-induced antinociception in wild-type mice. Although buprenorphine has been shown to interact with multiple opioid receptors, mice lacking $\mu$-opioid receptors failed to exhibit antinociception after buprenorphine administration. Our results indicate that the antinociceptive effect of buprenorphine in mice is $\mu$-opioid receptor-mediated yet severely compromised by concomitant activation of ORL-1 receptors.

Key words: antinociception; buprenorphine; J-113397; etorphine; morphine; orphanin FQ/nociceptin; ORL-1 receptors; $\mu$-opioid receptors; knock-out mice; MAP kinase; tail-flick assay

\section{Introduction}

The synthetic oripavine buprenorphine is a mixed agonist-antagonist at the classical $(\mu, \delta$, and $\kappa$ ) opioid receptors (for review, see Cowan, 1995; Rothman et al., 1995). Buprenorphine is an alternative medication to methadone in the treatment of heroin addicts (Mello et al., 1993; Ling et al., 1996, 1998; Litten and Allen, 1999; Johnson and McCagh, 2000) and also used as an analgesic (for review, see Finco et al., 1995; Picard et al., 1997). Subutex and suboxone tablets, which contain buprenorphine alone or a buprenorphine-naloxone mixture, respectively, were

Received June 23, 2003; revised Sept. 12, 2003; accepted Sept. 18, 2003.

This study was supported in part by National Institutes of Health Grants DA00411 (K.L.) and DA05010 and DA09359 (C.J.E.). K.L. was supported by National Institute on Drug Abuse Grant DA00411 and a National Alliance for Research on Schizophrenia and Depression Young Investigator Award. F.I.C. was supported by National Institutes of Health Grant DA09045. We thank Dr. Roberto Polakiewicz for providing valuable reagents for conducting the kinase assays.

Correspondence should be addressed to Dr. Kabirullah Lutfy at his present address: Department of Pharmaceutical Sciences, Western University of Health Sciences, 309 East Second Street, Pomona, CA 91766. E-mail klutfy@westernu.edu.

Copyright $\odot 2003$ Society for Neuroscience $\quad$ 0270-6474/03/2310331-07\$15.00/0 recently approved for opiate abuse treatment in the United States. Buprenorphine is also effective in treatment of refractory depression (Bodkin et al., 1995). In preclinical studies, buprenorphine initially showed great promise for the treatment of cocaine addiction; however, clinical trials have not been persuasive (for review, see Compton et al., 1995).

Of the clinically used opioid agonists, buprenorphine is considered exceptionally safe. The partial agonist activity at opioid receptors is generally believed to explain its safety, by providing a ceiling effect with regard to $\mu$-opioid receptor-mediated respiratory depression (Walsh et al., 1994). Overdose mortality has been reported only in cases of coabuse with other drugs such as benzodiazepines (Reynaud et al., 1998). Overall, the safety aspects of buprenorphine provide a compelling rationale for many clinical applications.

Analysis of the action of buprenorphine in vivo shows that the drug has a unique and complex pharmacology (for review, see Cowan, 1995). Buprenorphine has a long duration of action, and discontinuation of the drug appears to elicit limited withdrawal symptoms (Martin et al., 1976; Cowan et al., 1977a,b; Jacob and 
Ramabadran, 1978; Jasinski et al., 1978; Dum et al., 1981). At low doses, buprenorphine is an effective analgesic, but, at higher doses, the antinociceptive effect of the drug is often diminished (Dum et al., 1981; Lizasoain et al., 1991). This bell-shaped doseresponse curve has raised questions regarding the in vivo receptor pharmacology of buprenorphine. Partial agonism at opioid receptors has been considered as the underlying mechanism for the submaximal opiate-like pharmacological effects of buprenorphine (for review, see Heel et al., 1979; Lewis, 1985). However, partial agonist activity does not provide a satisfactory rationale for a bell-shaped dose-response curve.

Activation of the classical opioid receptors produces antinociception, whereas activation of supraspinal opioid receptor-like (ORL-1) receptors is pronociceptive or, at least, opposes opioid receptor-mediated antinociception (for review, see Mogil and Pasternak, 2001). Recently, buprenorphine has been shown to activate ORL-1 receptors (Wnendt et al., 1999; Bloms-Funke et al., 2000; Hawkinson et al., 2000; Huang et al., 2001), leading to the hypothesis that buprenorphine-induced antinociception may be modified by concomitant activation of ORL-1 receptors. Here, we demonstrate that buprenorphine is a partial agonist at $\mu$-opioid receptors and a full agonist at ORL- 1 receptors for activation of kinase cascades in vitro. Furthermore, using mice lacking $\mu$ or ORL-1 receptors, along with pharmacological tools, we show that buprenorphine-induced antinociception is mediated by $\mu$-opioid receptors and modified by ORL-1 receptor activation.

\section{Materials and Methods}

Subjects. Male ORL-1 receptor knock-out mice (Nishi et al., 1997) and their wild-type littermates were assayed at $10-12$ weeks after birth. $\mu$-Opioid receptor knock-out and wild-type mice, fully backcrossed to C57BL/6J background, were the offspring of heterozygote mice (Matthes et al., 1996). Mice were housed two to four per cage with access to food and water ad libitum in a $12 \mathrm{hr}$ light/dark cycle. All experiments were conducted in accordance with the National Institutes of Health Guide for the Care and Use of Laboratory Animals and were approved by the Institutional Animal Care and Use Committee. Mice were housed in the testing room for at least $4 \mathrm{~d}$ before experimentation and remained there until the end of the experiment. All experiments were conducted during the light phase by a researcher blind to the genotype of the mice.

Drugs. Morphine and OFQ/N were purchased from Mallinckrodt (St. Louis, MO) and Phoenix Pharmaceuticals (Belmont, CA), respectively. Buprenorphine and etorphine were kindly provided by the National Institute on Drug Abuse Drug Supply Program (Research Triangle Institute, Research Triangle Park, NC). The ORL-1 antagonist ( \pm )-J-113397 (1- $[(3 R, 4 R)-1$-cyclooctylmethyl-3- hydroxymethyl-4-piperidyl]-3ethyl-1, 3-dihydro-2 H-benzimidazol-2-one) was synthesized (Research Triangle Park) by a modification of the procedure reported previously (Kawamoto et al., 1999).

Cell lines. Chinese hamster ovary $(\mathrm{CHO})$ cells were transfected with the human ORL-1 receptor (CHO-ORL-1) or the murine $\mu$-opioid receptor (CHO-MOR), as described previously (Kaufman et al., 1995; Keith et al., 1996). Transfected and nontransfected cells were grown in DMEM containing $2 \mathrm{~mm}$ L-glutamine, $10 \%$ fetal bovine serum, $100 \mathrm{U} / \mathrm{ml}$ penicillin-G, $100 \mathrm{U} / \mathrm{ml}$ streptomycin, and $0.25 \mu \mathrm{g} / \mathrm{ml}$ amphotericin B (Omega Scientific, Tarzana, CA).

Assays for phosphorylation of mitogen-activated protein kinase and Akt. Two days before the assay, MOR- or ORL-1-transfected cells were cultured in DMEM containing 1\% fetal calf serum, followed by serum starvation for $2 \mathrm{hr}$ in DMEM containing $1 \mathrm{mg} / \mathrm{ml}$ bovine serum albumin and $50 \mathrm{~mm}$ HEPES. Cells were then treated for $5 \mathrm{~min}\left(37^{\circ} \mathrm{C}\right)$ with varying concentrations of ligand, followed by extraction with SDS sample buffer containing $62.5 \mathrm{~mm}$ Tris, $2 \%$ SDS, $10 \%$ glycerol, and $50 \mathrm{~mm}$ dithiotritol, pH 6.8. Samples were then sonicated to sheer DNA and were subjected to $10 \%$ SDS-PAGE, followed by Western blotting. Phosphorylated Akt and mitogen-activated protein (MAP) kinase were detected using specific rabbit phospho-Akt and phospho-MAP kinase antibodies (Cell Signaling Technology, Beverly, MA), followed by peroxidase-conjugated secondary antisera (Bio-Rad, Hercules, CA) and ECL detection. Antibodies directed against Akt (Cell Signaling Technology) were used to control for kinase protein levels. For quantification, films were scanned using a UMAX Astra 3450 scanner and analyzed using NIH Image 1.62 (National Institutes of Health, Bethesda, $\mathrm{MD}$ ). $\mathrm{EC}_{50}$ and $E_{\max }$ were calculated using Prism 3 (GraphPad Software, San Diego, CA).

Nociceptive assay. The tail-flick assay was used to examine the antinociceptive effect of buprenorphine in wild-type and ORL-1 or $\mu$-opioid receptor knock-out mice. Briefly, a beam of light was focused on the dorsal surface of the mouse's tail $\sim 2.5 \mathrm{~cm}$ from the tip of the tail. The intensity of the light was adjusted so that the baseline latencies averaged between 3 and $4 \mathrm{sec}$. A cutoff time of $15 \mathrm{sec}$ was used as the maximum possible effect to minimize tissue damage. Initially, mice were tested for baseline latencies and then, $30 \mathrm{~min}$ later, injected with cumulative doses of either buprenorphine $(0.1,0.3,1$, and $3 \mathrm{mg} / \mathrm{kg}$, s.c.) or morphine (2.5, 5.0 , and $10.0 \mathrm{mg} / \mathrm{kg}$, s.c.), and tested for a postdrug tail-flick latency $15 \mathrm{or}$ 30 min later, respectively. Each experiment was conducted at least twice.

The antinociceptive effect of buprenorphine was also examined in the presence of J-113397, an ORL-1 receptor antagonist (Kawamoto et al., 1999), in mice lacking the ORL-1 receptor and their wild-type littermates. Mice were initially tested for baseline and, after a $30 \mathrm{~min}$ delay, treated with J-113397 (3 mg/kg, i.p.) or vehicle (20\% DMSO in saline) Fifteen minutes later, mice were injected with buprenorphine $(0.3 \mathrm{mg} /$ $\mathrm{kg}$, s.c.) and tested after an additional 15 min delay. The effect of J-113397 alone on nociceptive responses was also determined in wild-type mice $(n=5)$. Mice were tested for baseline and injected, $30 \mathrm{~min}$ later, with J-113397 (3 mg/kg, i.p.) and tested 15, 30, and $60 \mathrm{~min}$ later.

At a higher light intensity, which yielded averaged baseline of $\sim 1.6 \mathrm{sec}$, buprenorphine was found to elicit antinociception in a bell-shaped manner. The effect of J-113397 on this bell-shaped dose-response curve was also studied. Mice were tested for baseline latencies and, after a $30 \mathrm{~min}$ delay, injected with vehicle ( $20 \% \mathrm{DMSO} ; n=8$ mice) or J-113397 (2 $\mathrm{mg} / \mathrm{kg}$, i.p.; $n=6$ mice). Fifteen minutes later, mice were injected with buprenorphine $(0.3,1$, or $3 \mathrm{mg} / \mathrm{kg}$, s.c.) and tested $15 \mathrm{~min}$ later. As control, a separate group of mice $(n=5)$ was tested for baseline and, after a $30 \mathrm{~min}$ delay, received J-113397 (2 mg/kg, i.p.). Fifteen minutes later, mice were injected with saline and tested after an additional $15 \mathrm{~min}$.

Data analysis. For dose-response studies, a two-way repeatedmeasure ANOVA was used. For single-dose studies, data were expressed as percentage maximum possible effect (\%MPE) according to the formula $[\% \mathrm{MPE}=(($ Test latency - Baseline $) /($ Cutoff - Baseline $)) * 100]$ and analyzed using a two-factor ANOVA. The Newman-Keuls post hoc test was then used to reveal significant differences between different genotypes and doses of the drug. A value of $p<0.05$ was considered statistically significant.

\section{Results}

\section{Buprenorphine is a partial agonist at activating kinase} signaling via $\boldsymbol{\mu}$-opioid receptors

In $\mathrm{CHO}$ cells expressing the $\mu$-opioid receptors (CHO-MOR cells), buprenorphine and etorphine activated both MAP kinase and Akt at low nanomolar concentrations (Fig. 1). MAP kinase activation was semiquantified as described in Materials and Methods. The calculated $E_{\max }$, for activation of MAP kinase, was only $42.97 \pm 4.65 \%$ of etorphine $(1 \mu \mathrm{M})$. This datum suggests that buprenorphine acts as a partial agonist for MAP kinase signaling at $\mu$-opioid receptors compared with etorphine. Furthermore, buprenorphine was less potent than etorphine (Fig. $1 B$ ).

Buprenorphine, but not morphine, activates MAP kinase and Akt via ORL-1 receptors

In $\mathrm{CHO}$ cells expressing ORL-1 receptors (CHO-ORL-1), buprenorphine behaved as a full agonist to activate MAP kinase and Akt. However, buprenorphine was found to be a low-potency 
A.

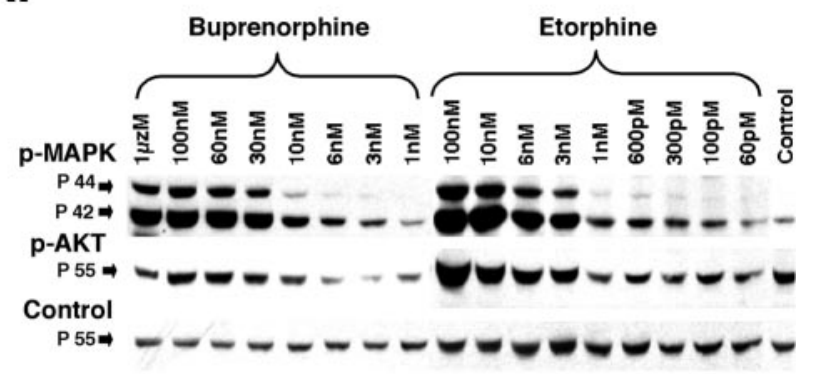

B.

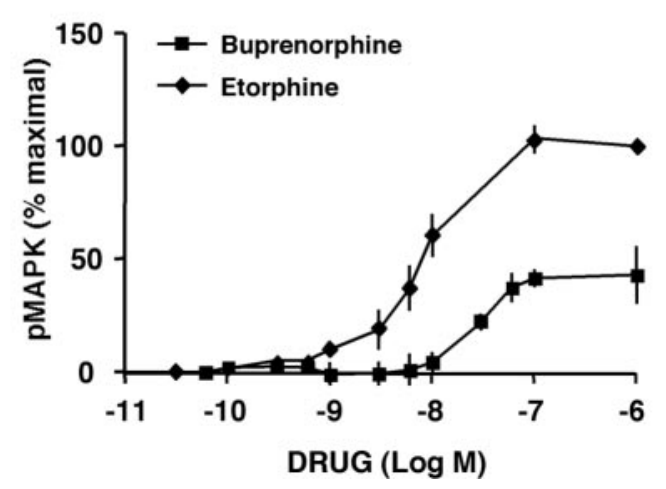

Figure 1. Buprenorphine is a partial agonist for Akt and MAP kinase activation via $\mu$-opioid receptors. Kinase activation was determined in CHO-MOR cells by Western blot analysis using phospho-specific MAP kinase and Akt antisera (for details, see Materials and Methods). An antisera directed to Akt was used to control for loading protein levels. A shows that buprenorphine and etorphine each concentration dependently activated MAP kinase and Akt. $B$ shows semiquantification of MAP kinase activation by buprenorphine and etorphine (maximal activation is defined as that induced by $1 \mu \mathrm{m}$ etorphine). Results are presented as mean \pm SEM.

agonist compared with $\mathrm{OFQ} / \mathrm{N}$ (Fig. 2A,B). Morphine, on the other hand, was unable to activate MAP kinase or Akt in CHOORL- 1 cells, even at concentrations up to $100 \mu \mathrm{M}$ (Fig. 2 B). Buprenorphine and $\mathrm{OFQ} / \mathrm{N}$ each failed to activate MAP kinase in CHO-ORL-1 cells in the presence of $10 \mu \mathrm{M} \mathrm{J-113397} \mathrm{(Fig.} \mathrm{2C).}$ No activation of kinases by buprenorphine or $\mathrm{OFQ} / \mathrm{N}$ was observed in nontransfected $\mathrm{CHO}$ cells (data not shown).

Buprenorphine fails to produce antinociception in mice lacking $\boldsymbol{\mu}$-opioid receptors

$\mu$-Opioid receptor knock-out mice and wild-type controls $(n=$ 5-6 mice per genotype) were tested before and $15 \mathrm{~min}$ after buprenorphine $(0.1-3.0 \mathrm{mg} / \mathrm{kg}$, s.c.) administration using the tailflick assay (Fig. 3). A two-way repeated-measure ANOVA revealed a main effect of genotype $\left(F_{(1,9)}=25.34 ; p<0.05\right)$, a main effect of dose $\left(F_{(3,27)}=3.10 ; p<0.05\right)$, and an interaction between genotype and dose $\left(F_{(3,27)}=7.80, p<0.05\right)$. Post hoc analysis of the data revealed a dose-dependent increase in buprenorphine-induced antinociception in wild-type mice and no antinociception at any dose in $\mu$-opioid receptor knock-out mice. These results indicate that the $\mu$-opioid receptor is required for the antinociceptive effect of buprenorphine.

Buprenorphine-induced antinociception is enhanced in mice lacking ORL-1 receptors

ORL-1 receptor knock-out mice and their wild-type littermates ( $n=7-8$ mice per genotype) were tested before and $15 \mathrm{~min}$ after buprenorphine $(0.1-3.0 \mathrm{mg} / \mathrm{kg}$, s.c.) administration (Fig. 4). A
A.

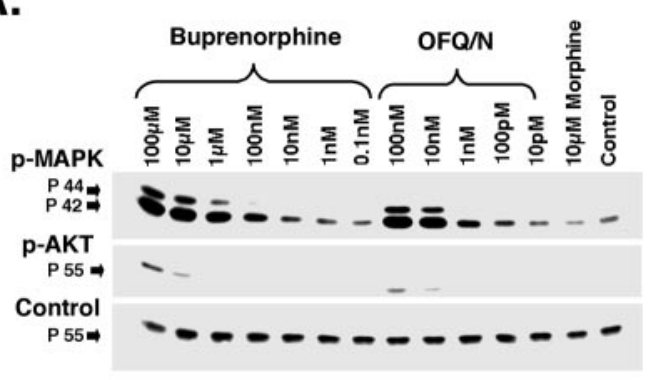

B.

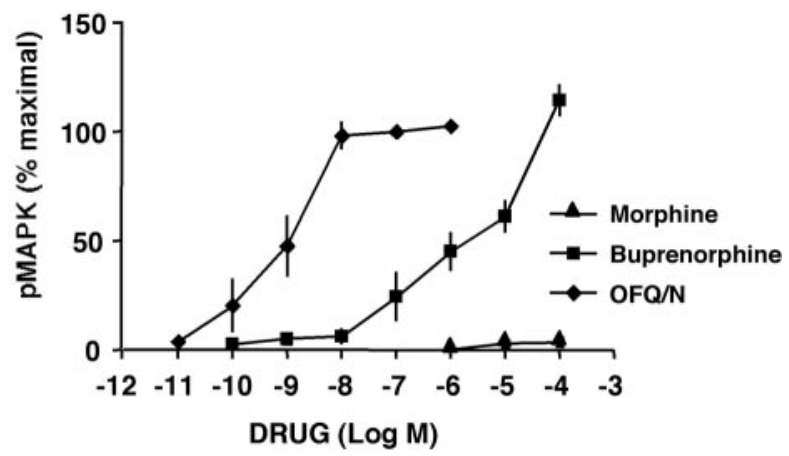

C.

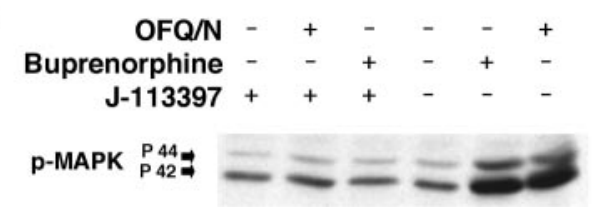

Figure 2. Buprenorphine is a highly efficacious agonist for Akt and MAP kinase activation via ORL-1 receptors. Kinase activation was determined in $\mathrm{CHO}-0 \mathrm{RL}-1$ cells by Western blot analysis using phospho-specific antisera (for details, see Materials and Methods). A shows that buprenorphine, similar to $0 \mathrm{FQ} / \mathrm{N}$, concentration dependently activated MAP kinase and Akt, whereas morphine failed to produce activation of either kinase. $B$ shows semiquantification of MAP kinase activation by buprenorphine, morphine, and OFQ/N (maximal activation is defined as that induced by $100 \mathrm{~nm} 0 \mathrm{FQ} / \mathrm{N}$ ). Similar maximum efficacy was obtained for buprenorphine and $\mathrm{OFQ} / \mathrm{N}$ in activating MAP kinase, albeit $\mathrm{OFQ} / \mathrm{N}$ was substantially more potent than buprenorphine. Morphine shows no significant activation of MAP kinase in CHO-ORL-1 cells, even at concentrations of up to $100 \mu \mathrm{m}$. Results are presented as mean \pm SEM. C demonstrates that the ORL-1 antagonist J-113397 blocks the activation of MAP kinase induced by OFQ/N or buprenorphine, yet has no modulatory effect on phospho-MAP kinase alone.

two-way repeated-measure ANOVA revealed a main effect of genotype $\left(F_{(1,13)}=9.60 ; p<0.05\right)$, a main effect of dose $\left(F_{(3,39)}=\right.$ $46.83 ; p<0.05)$, and an interaction between genotype and dose $\left(F_{(3,39)}=4.77 ; p<0.05\right)$. Post hoc analysis of the data revealed a significant difference in buprenorphine-induced antinociception at $0.3,1.0$, and $3.0 \mathrm{mg} / \mathrm{kg}$ but not at $0.1 \mathrm{mg} / \mathrm{kg}$. These data reveal that, at doses of $0.3 \mathrm{mg} / \mathrm{kg}$ and above, the antinociceptive effect of buprenorphine was significantly enhanced in the ORL-1 receptor knock-out mice.

Unlike buprenorphine, morphine produced a similar dosedependent antinociceptive effect in both wild-type and ORL-1 receptor knock-out mice (Fig. 5). There was a main effect of dose $\left(F_{(2,36)}=113.91 ; p<0.05\right)$ but not genotype $\left(F_{(1,18)}=1.16 ; p>\right.$ $0.05)$ or interaction between dose and genotype $\left(F_{(2,36)}=1.24\right.$; $p>0.05)$. Post hoc analysis of the data revealed that morphine dose dependently produced antinociception, and there was no significant difference in morphine-induced antinociception 


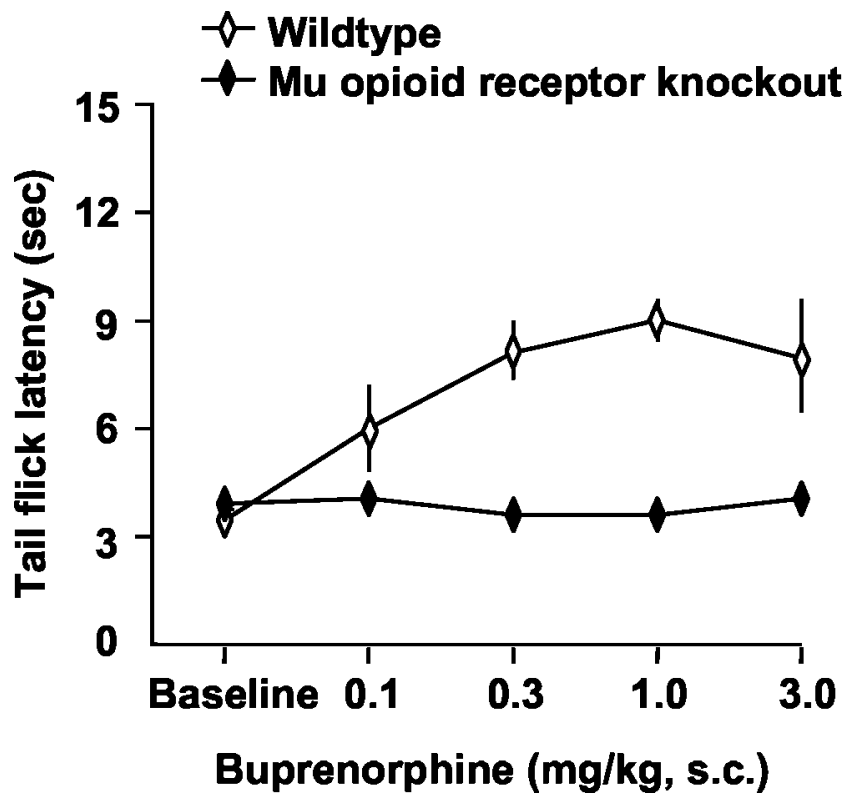

Figure 3. Buprenorphine fails to produce antinociception in mice lacking $\mu$-opioid receptors. Mice were tested for baseline tail-flick latency, injected with buprenorphine $(0.1-3.0 \mathrm{mg} / \mathrm{kg}$, S.c.), and tested for postdrug latency $15 \mathrm{~min}$ later. Results are presented as mean \pm SEM.

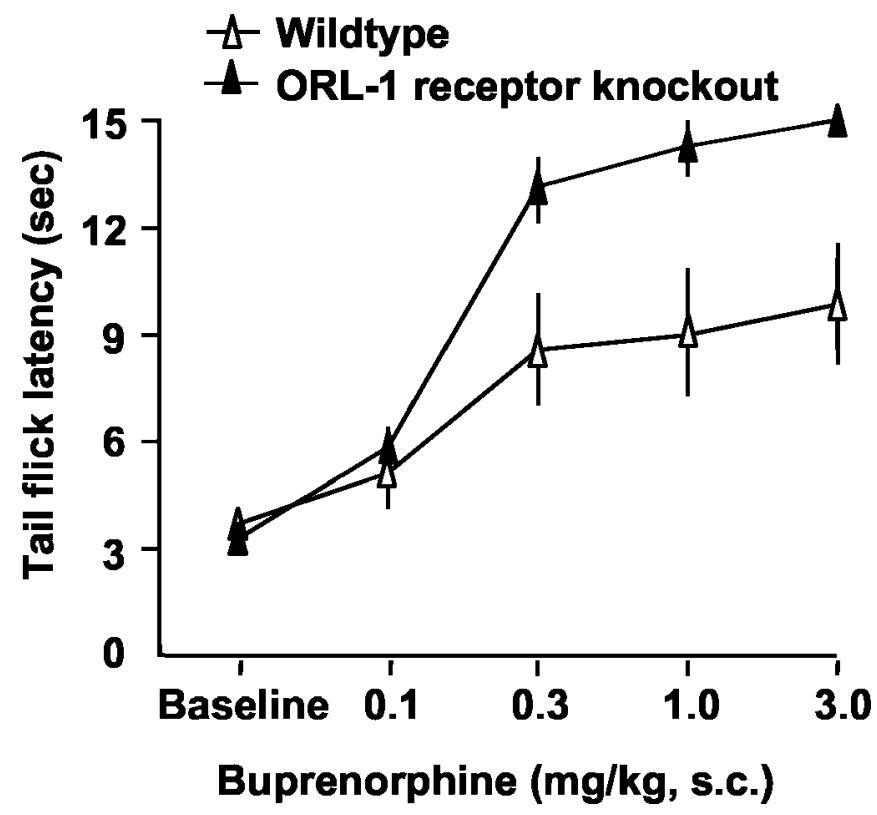

Figure 4. The antinociceptive effect of buprenorphine is significantly enhanced in ORL-1 receptor knock-out mice. Mice lacking the ORL-1 receptor and their wild-type littermates were tested for baseline tail-flick latency, injected with buprenorphine (0.1-3.0 mg/kg, s.c.), and tested for postdrug latency after a 15 min delay. Results are presented as mean \pm SEM.

between mice lacking ORL-1 receptors and their wild-type littermate controls.

Buprenorphine-induced antinociception is enhanced in the presence of the ORL-1 receptor antagonist J-113397

The effect of the ORL-1 receptor antagonist J-113397 (3 mg/kg, i.p.) on buprenorphine-induced antinociception was then assessed in both wild-type and ORL-1 receptor knock-out mice (Fig. 6). There was a main effect of treatment $\left(F_{(1,19)}=4.72\right.$; $p<0.05)$ and an interaction between treatment and genotype $\left(F_{(1,19)}=5.27 ; p<0.05\right)$. Post hoc analysis of the data revealed

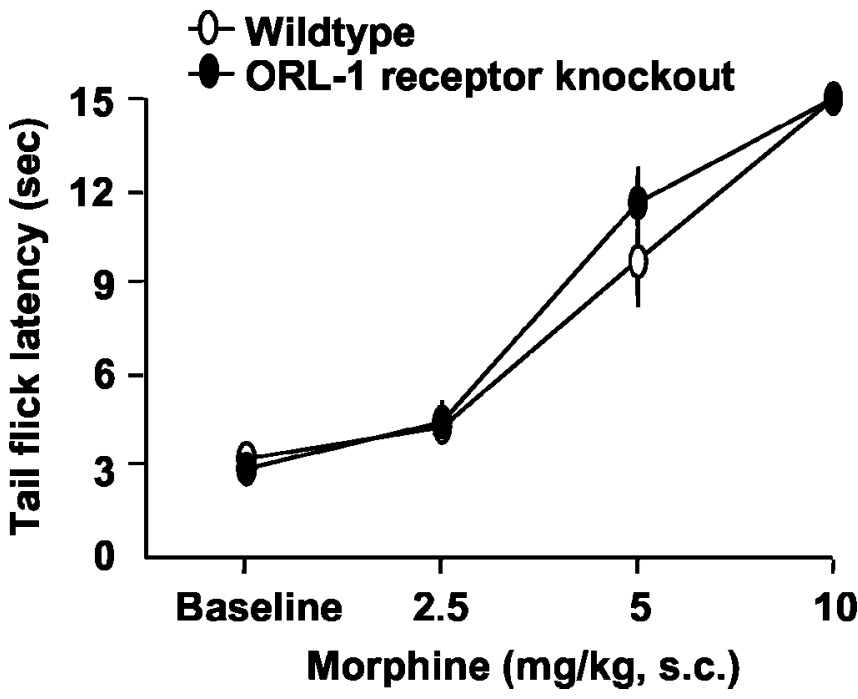

Figure 5. The antinociceptive effect of morphine is unaltered in ORL-1 receptor knock-out mice. Mice lacking the ORL-1 receptor and their wild-type littermates were tested for baseline tail-flick latency, injected with morphine (2.5-10.0 mg/kg, s.c.), and tested for postdrug latency $30 \mathrm{~min}$ later. Results are presented as mean \pm SEM.

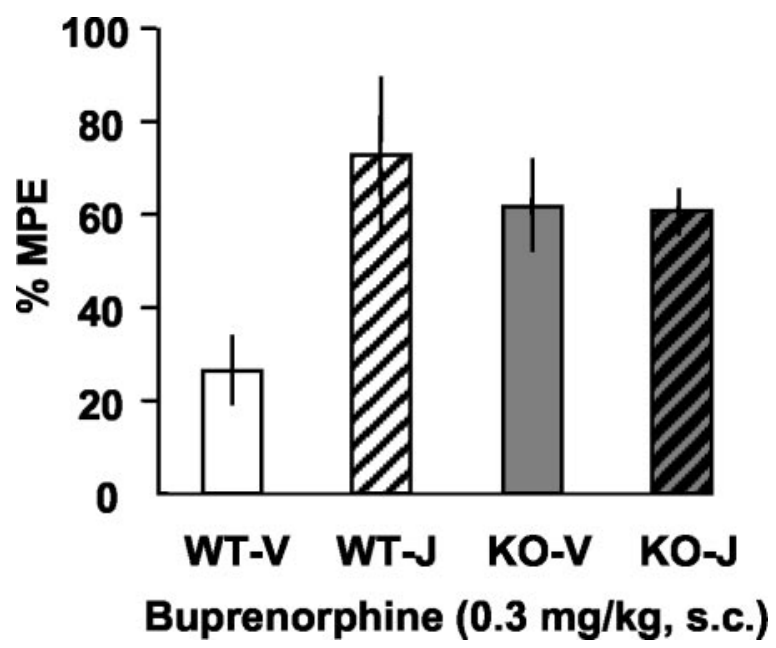

Figure 6. The antinociceptive effect of buprenorphine was enhanced by J-113397. Mice were tested for baseline tail-flick latency, injected with either vehicle (V; 20\% DMSO) or J-113397 (J;3 $\mathrm{mg} / \mathrm{kg}$, i.p.), followed, $15 \mathrm{~min}$ later, by buprenorphine $(0.3 \mathrm{mg} / \mathrm{kg}$, s.c.), and tested for postdrug latency after an additional $15 \mathrm{~min}$ delay. Results are presented as mean \pm SEM.

that the antinociceptive effect of buprenorphine was significantly increased in the presence of J-113397 in wild-type mice $(p<$ $0.05)$ but not ORL-1 receptor knock-out mice $(p>0.05)$. Importantly, our pilot study showed that J-113397 alone had no significant effect on nociceptive responses in wild-type mice [3.48 \pm 0.12 (baseline) vs $3.14 \pm 0.22$ (15 min later) vs $3.24 \pm$ 0.33 (30 min later) vs $3.18 \pm 0.33$ (60 min later)]. These pharmacological data provide additional evidence that ORL-1 receptors play a modulatory role in buprenorphine-induced antinociception.

J-113397 eliminates the bell-shaped dose-response curve of buprenorphine in wild-type mice

Buprenorphine has often been reported to produce antinociception in a bell-shaped manner. However, we were unable to obtain a bell-shaped dose-response curve for buprenorphine using low light intensity in the tail-flick assay. Therefore, we examined 


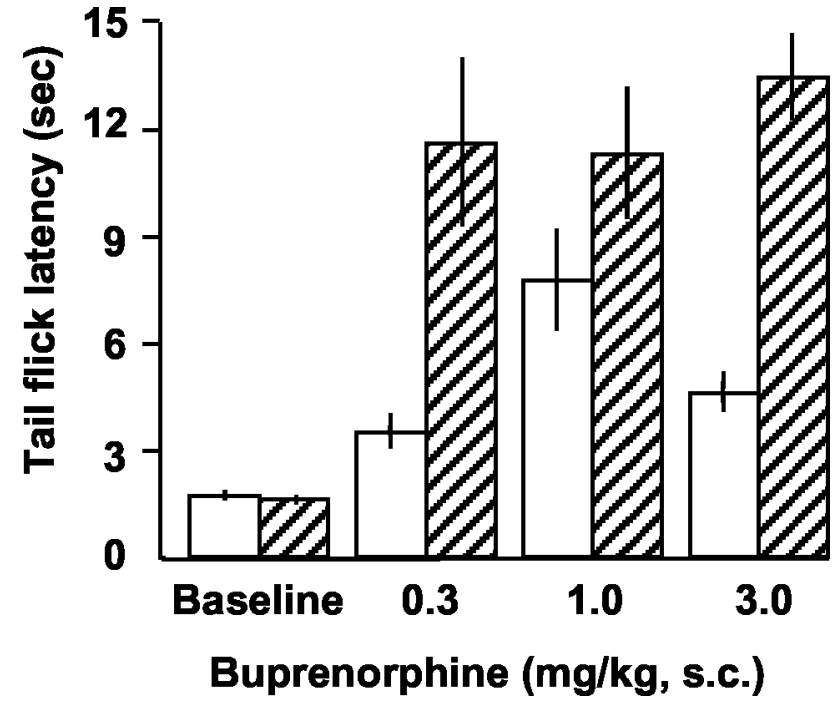

Figure 7. The bell-shaped dose-response curve for buprenorphine-induced antinociception is eliminated by J-113397. Mice were tested for baseline tail-flick latency using a high light intensity. Mice were then injected with either vehicle (20\% DMSO; open bars) or J-113397 (2 $\mathrm{mg} / \mathrm{kg}$, i.p.; hatched bars), followed, $15 \mathrm{~min}$ later, by buprenorphine $(0.3,1.0$, or $3.0 \mathrm{mg} / \mathrm{kg}$, s.c.) and tested for postdrug latency after an additional 15 min delay. Results are presented as mean \pm SEM.

whether buprenorphine would produce a bell-shaped doseresponse curve using higher light intensities, and if so, whether this bell-shaped dose-response curve would be attributed to ORL-1 receptor activation (Fig. 7). A two-way repeated-measure ANOVA revealed a main effect of treatment [J-113397 $(2 \mathrm{mg} / \mathrm{kg}$, i.p) vs vehicle] $\left(F_{(1,12)}=24.04 ; p<0.05\right)$ and an interaction between treatment and buprenorphine doses $\left(F_{(2,24)}=3.21 ; p<\right.$ 0.05). Post hoc analysis of the data showed that buprenorphine alone produced a bell-shaped dose-response curve, i.e., a significantly greater antinociception was observed at $1.0 \mathrm{mg} / \mathrm{kg}$ compared with $0.3 \mathrm{mg} / \mathrm{kg}$ and significantly lower antinociception at $3.0 \mathrm{mg} / \mathrm{kg}$ compared with $1.0 \mathrm{mg} / \mathrm{kg}$ buprenorphine. In contrast, in the presence of J-113397, the bell-shaped dose-response curve of buprenorphine was eliminated such that there was no significant difference in buprenorphine-induced antinociception after 0.3, 1.0, or $3.0 \mathrm{mg} / \mathrm{kg}$ buprenorphine. These data indicate that a bell-shaped dose-response curve for buprenorphine-induced antinociception can be observed with the increased light intensity in the tail-flick assay. Furthermore, this bell-shaped dose-response curve was eliminated after blockade of ORL-1 receptors. As shown above, J-113397 (2 mg/kg, i.p.), injected $15 \mathrm{~min}$ before saline, had no significant effect on nociceptive responses $(p>0.05)$.

\section{Discussion}

Opioid analgesics are routinely used for treatment of moderateto-severe pain. However, side effects associated with the acute and chronic use of opioids, such as respiratory depression, constipation, tolerance, and dependence, have made physicians wary of prescribing these drugs. Among the many opioid drugs available, buprenorphine has some unique and attractive properties for clinical applications. Buprenorphine has only mild effects on the digestive system, does not itself cause lethality via respiratory depression, and is a long-lasting drug that reduces craving and elicits few withdrawal symptoms (for review, see Tzschentke, 2002). For these reasons, buprenorphine is becoming a preferred drug for maintenance therapy of opiate addicts (Lewis and Walter, 1992; Mello et al., 1993; Ling et al., 1996, 1998; Litten and
Allen, 1999; Johnson and McCagh, 2000), yet the drug has a complex in vivo pharmacology with aspects not well understood.

In common with most clinically used opioid analgesics, buprenorphine does not have absolute selectivity for one type of opioid receptor. Buprenorphine has been shown to act as a partial agonist at $\mu$-opioid receptors (Cowan et al., 1977a,b; Dum et al. 1981; Lizasoain et al., 1991). It also acts as an agonist (Tyers, 1980 ) or antagonist (Leander, 1988) at $\kappa$-opioid receptors. Moreover, in some systems, buprenorphine behaves as an antagonist at $\delta$-opioid receptors (Sadee et al., 1982). Agonist-induced phosphorylation of MAP kinase and Akt in CHO cells transfected with $\mu$-opioid receptors (CHO-MOR) supports the notion that buprenorphine, compared with etorphine, is a partial agonist at $\mu$-opioid receptors (Fig. 1). Although interacting with multiple opioid receptors, buprenorphine exhibited no antinociception in mice lacking the $\mu$-opioid receptor (Fig. 3 ), suggesting that the antinociceptive effect of buprenorphine is primarily mediated by $\mu$-opioid receptors. This finding, however, does not exclude the potential for other opioid receptors to contribute to the antinociceptive effect of buprenorphine. For example, the signaling actions at multiple opioid receptors may be synergistic. Alternatively, formation of specific opioid receptor complexes, e.g., via heterodimerization (Jordan et al., 2001), may be essential for antinociception induced by some opiate drugs.

In both animals and humans, a hallmark of the antinociceptive action of buprenorphine is the production of a ceiling effect or bell-shaped dose-response curve (for review, see Cowan, 1995; Rothman et al., 1995). In the present study, using different light intensities in the tail-flick assay, we observed either a ceiling effect or a bell-shaped dose-response relationship for buprenorphineinduced antinociception. One very plausible explanation for the observed ceiling effect is that buprenorphine behaves as a partial agonist at the $\mu$-opioid receptor, a property clearly evident from the in vitro signaling data (Fig. 1). However, a bell-shaped doseresponse curve does not fit well with a hypothesis of partial agonist activity. An alternative explanation is that buprenorphine coactivates receptors other than classical opioid receptors and this compromises its antinociceptive efficacy.

An obvious receptor target for buprenorphine, other than the classical opioid receptors, is the ORL-1 receptor, which shares considerable structural homology with the classical opioid receptors (Bunzow et al., 1994; Chen et al., 1994; Fukuda et al., 1994; Mollereau et al., 1994). Activation of the ORL-1 receptor was thought to induce hyperalgesia, an effect that led Meunier et al. (1995) to name the endogenous ligand of the ORL-1 receptor, nociceptin. Subsequent studies, however, have attributed this hyperalgesia (Reinscheid et al., 1995) to blockade of stress-induced antinociception and proposed OFQ/N to be an anti-opioid peptide with regard to modulation of nociception (for review, see Mogil and Pasternak, 2001). Thus, activation of supraspinal ORL-1 receptors by intracerebroventricular OFQ/N administration can effectively block the antinociceptive actions of $\mu$-, $\delta$-, and $\kappa$-opioid receptor agonists (Mogil et al., 1996). In contrast, activation of spinal ORL-1 receptors after intrathecal OFQ/N administration leads to antinociception in the tail-flick assay (for review, see Mogil and Pasternak, 2001).

Buprenorphine has been shown previously to act at ORL-1 receptors as an agonist in several signaling pathways (Wnendt et al., 1999; Bloms-Funke et al., 2000; Hawkinson et al., 2000; Huang et al., 2001). Here, we demonstrate that buprenorphine can activate both MAP kinase and Akt via activation of ORL-1 receptors expressed in $\mathrm{CHO}$ cells. However, the efficacy of buprenorphine for kinase activation was considerably greater via 
ORL-1 receptors compared with $\mu$-opioid receptors. Although not strictly comparable, a similar percentage of maximum kinase activation was observed in both CHO-ORL-1 and CHO-MOR cell lines at lower buprenorphine concentrations (Figs. $1 \mathrm{~B}, 2 \mathrm{~B}$ ). Thus, we initially tested the hypothesis that activation of ORL-1 receptors may modulate buprenorphine-induced antinociception (Wnendt et al., 1999).

Predicting the potency or efficacy of buprenorphine for modulation of nociception via either $\mu$ or ORL- 1 receptors based on its in vitro pharmacological characteristics is not straightforward and depends on numerous factors, including the number of each of the receptors requiring activation to modulate nociceptive circuitry. We initially addressed the possible importance of ORL-1 receptors in modulating buprenorphine-induced antinociception using mice lacking ORL-1 receptors. The ORL-1 receptor knock-out mice showed dramatically increased buprenorphineinduced antinociception compared with wild types, suggesting that ORL-1 receptors were coactivated with $\mu$-opioid receptors by buprenorphine, and this activity could compromise the antinociceptive efficacy of buprenorphine. An alternative explanation could be that $\mu$-opioid receptor-mediated antinociception is enhanced in ORL-1 knock-out mice. However, this appears unlikely because the antinociceptive effect of morphine, demonstrated previously to be $\mu$-opioid receptor mediated (for review, see Kieffer, 1999), is indistinguishable at multiple doses between wild-type and ORL-1 receptor knock-out mice.

Because of the potential complexities associated with receptor knock-out mice, we also assessed the role of ORL-1 receptors in buprenorphine-induced antinociception using J-113397, an ORL-1 antagonist (Kawamoto et al., 1999). The antinociceptive effect of buprenorphine was significantly enhanced by coadministration of J-113397 in wild-type, but not ORL-1 receptor knock-out, mice. Moreover, wild-type mice treated with J-113397 showed indistinguishable buprenorphine-induced antinociception when compared with mice lacking ORL-1 receptors (Fig. 6). Importantly, J-113397 also eliminated the bellshaped dose-response curve exhibited by buprenorphine. Therefore, we attribute both the bell-shaped dose-response curve and low antinociceptive efficacy of buprenorphine to concomitant activation of ORL-1 receptors. Furthermore, our results, in conjunction with previous findings, suggest that activation of supraspinal ORL-1 receptors not only compromises the $\mu$-opioid receptor-mediated actions of buprenorphine but also overrides the possible spinal ORL-1 receptor-mediated antinociceptive effect of buprenorphine.

Many previous studies have reported a bell-shaped antinociceptive dose-response curve for buprenorphine. Using a low light intensity in the tail-flick assay, only a ceiling effect was observed. However, increasing the intensity of the noxious stimulus resulted in a bell-shaped dose-response curve after buprenorphine administration. Given this finding and that the bell-shaped dose-response curve of buprenorphine was eliminated by the ORL-1 receptor antagonist, we speculate that the contribution of ORL- 1 and $\mu$ receptors to buprenorphine-induced antinociception may be altered by the intensity of the noxious stimulus. Indeed, previous studies have shown that there are different patterns of CNS activation in response to different intensities of noxious stimulation (Derbyshire et al., 1997). Thus, at higher noxious stimuli, activation of ORL-1 receptors may, to a greater extent, compromise the $\mu$ receptor-mediated antinociceptive effect of buprenorphine.

The results of this study indicate that ORL-1 receptors can contribute to the actions of buprenorphine in vivo. Given the extensive and prominent distribution of ORL-1 receptors in the CNS and cells of the human immune system, this would imply that the ability of buprenorphine to activate ORL-1 receptors may also contribute to other pharmacological effects of the drug. It is not clear, however, whether ORL-1 receptors contribute to the safety characteristics of buprenorphine because ORL-1 receptor activation has been shown to decrease respiratory frequency (Takita et al., 2003).

Our results present a potential clinical strategy for increasing the analgesic efficacy of buprenorphine by coadministration of an ORL-1 receptor antagonist. However, ORL-1 receptor inactivation may have widespread adverse consequences and perhaps disrupt beneficial properties of buprenorphine, e.g., its actions on mood. A more satisfactory approach for more efficacious analgesics may be to use the pharmacophore of buprenorphine and develop analogs with no activity at ORL-1 receptors. Finally, our observation that buprenorphine-induced antinociception is compromised by coactivation of ORL-1 receptors provides a very attractive hypothesis to explain the low efficacy and the bellshaped dose-response curve for this widely used opiate drug.

\section{References}

Bloms-Funke P, Gillen C, Schuettler AJ, Wnendt S (2000) Agonistic effects of the opioid buprenorphine on the nociceptin/OFQ receptor. Peptides 21:1141-1146.

Bodkin JA, Zornberg GL, Lukas SE, Cole JO (1995) Buprenorphine treatment of refractory depression. J Clin Psychopharmacol 15:49-57.

Bunzow JR, Saez C, Mortrud M, Bouvier C, Williams JT, Low M, Grandy DK (1994) Molecular cloning and tissue distribution of a putative member of the rat opioid receptor gene family that is not a mu, delta or kappa opioid receptor type. FEBS Lett 347:284-288.

Chen Y, Fan Y, Liu J, Mestek A, Tian M, Kozak CA, Yu L (1994) Molecular cloning, tissue distribution and chromosomal localization of a novel member of the opioid receptor gene family. FEBS Lett 347:279-283.

Compton PA, Ling W, Charuvastra VC, Wesson DR (1995) Buprenorphine as a pharmacotherapy for cocaine abuse: a review of the evidence. J Addict Dis 14:97-114.

Cowan A (1995) Update of the general pharmacology of buprenorphine. In: Buprenorphine: combating drug abuse with a unique opioid (Lewis J, Cowan A, eds), pp 31-47. New York: Wiley.

Cowan A, Lewis JW, Macfarlane IR (1977a) Agonist and antagonist properties of buprenorphine, a new antinociceptive agent. $\mathrm{Br} \mathrm{J}$ Pharmacol 60:537-545.

Cowan A, Doxey JC, Harry EJ (1977b) The animal pharmacology of buprenorphine, an oripavine analgesic agent. Br J Pharmacol 60:547-554.

Derbyshire SW, Jones AK, Gyulai F, Clark S, Townsend D, Firestone LL (1997) Pain processing during three levels of noxious stimulation produces differential patterns of central activity. Pain 73:431-445.

Dum J, Blasig J, Herz A (1981) Buprenorphrine: demonstration of physical dependence liability. Eur J Pharmacol 70:293-300.

Finco G, Polati E, Gottin L, Bartoloni A, Milan B, Zanoni L, Valle L (1995) Intravenous patient-controlled analgesia (PCA) in the treatment of postoperative pain: rationale and clinical application. Chir Ital 47:20-25.

Fukuda K, Kato S, Mori K, Nishi M, Takeshima H, Iwabe N, Miyata T, Houtani T, Sugimoto T (1994) cDNA cloning and regional distribution of a novel member of the opioid receptor family. FEBS Lett 343:42-46.

Hawkinson JE, Acosta-Burruel M, Espitia SA (2000) Opioid activity profiles indicate similarities between the nociceptin/orphanin FQ and opioid receptors. Eur J Pharmacol 389:107-114.

Heel RC, Brogden RN, Speight TM, Avery GS (1979) Buprenorphine: a review of its pharmacological properties and therapeutic efficacy. Drugs 17:81-110.

Huang P, Kehner GB, Cowan A, Liu-Chen LY (2001) Comparison of pharmacological activities of buprenorphine and norbuprenorphine: norbuprenorphine is a potent opioid agonist. J Pharmacol Exp Ther 297:688-695.

Jacob JJ, Ramabadran K (1978) Enhancement of a nociceptive reaction by opioid antagonists in mice. Br J Pharmacol 64:91-98.

Jasinski DR, Pevnick JS, Griffith JD (1978) Human pharmacology and abuse potential of the analgesic buprenorphine: a potential agent for treating narcotic addiction. Arch Gen Psychiatry 35:501-516. 
Johnson RE, McCagh JC (2000) Buprenorphine and naloxone for heroin dependence. Curr Psychiatry Rep 2:519-526.

Jordan BA, Trapaidze N, Gomes I, Nivarthi R, Devi LA (2001) Oligomerization of opioid receptors with beta 2 -adrenergic receptors: a role in trafficking and mitogen-activated protein kinase activation. Proc Natl Acad Sci USA 98:343-348.

Kaufman DL, Keith Jr DE, Anton B, Tian J, Magendzo K, Newman D, Tran TH, Lee DS, Wen C, Xia Y-R, Lusis AJ, Evans CJ (1995) Characterization of the murine mu opioid receptor gene. J Biol Chem 70:15877-15883.

Kawamoto H, Ozaki S, Itoh Y, Miyaji M, Arai S, Nakashima H, Kato T, Ohta H, Iwasawa Y (1999) Discovery of the first potent and selective small molecule opioid receptor-like (ORL1) antagonist: 1-[(3R, 4R)-1cyclooctylmethyl-3- hydroxymethyl-4-piperidyl]-3-ethyl-1, 3-dihydro2H-benzimidazol-2-one (J-113397). J Med Chem 42:5061-5063.

Keith Jr DE, Murray SR, Zaki PA, Chu PC, Lissin DV, Kang L, Evans CJ, von Zastrow M (1996) Morphine activates opioid receptors without causing their rapid internalization. J Biol Chem 271:19021-19024.

Kieffer BL (1999) Opioids: first lessons from knockout mice. Trends Pharmacol Sci 20:19-26.

Leander JD (1988) Buprenorphine is a potent kappa-opioid receptor antagonist in pigeons and mice. Eur J Pharmacol 151:457-461.

Lewis JW (1985) Buprenorphine. Drug Alcohol Depend 14:363-372.

Lewis JW, Walter D (1992) Buprenorphine-background to its development as a treatment for opiate dependence. NIDA Res Monogr 121:5-11.

Ling W, Wesson DR, Charuvastra C, Klett CJ (1996) A controlled trial comparing buprenorphine and methadone maintenance in opioid dependence. Arch Gen Psychiatry 53:401-407.

Ling W, Charuvastra C, Collins JF, Batki S, Brown Jr LS, Kintaudi P, Wesson DR, McNicholas L, Tusel DJ, Malkerneker U, Renner Jr JA, Santos E, Casadonte P, Fye C, Stine S, Wang RI, Segal D (1998) Buprenorphine maintenance treatment of opiate dependence: a multicenter, randomized clinical trial. Addiction 93:475-486.

Litten RZ, Allen JP (1999) Medications for alcohol, illicit drug, and tobacco dependence. An update of research findings. J Subst Abuse Treat $16: 105-112$

Lizasoain I, Leza JC, Lorenzo P (1991) Buprenorphine: bell-shaped doseresponse curve for its antagonist effects. Gen Pharmacol 22:297-300.

Martin WR, Eades CG, Thompson JA, Huppler RE, Gilbert PE (1976) The effects of morphine- and nalorphine- like drugs in the nondependent and morphine-dependent chronic spinal dog. J Pharmacol Exp Ther 197:517-532.

Matthes HW, Maldonado R, Simonin F, Valverde O, Slowe S, Kitchen I, Befort K, Dierich A, Le Meur M, Dolle P, Tzavara E, Hanoune J, Roques BP, Kieffer BL (1996) Loss of morphine-induced analgesia, reward effect and withdrawal symptoms in mice lacking the mu-opioid-receptor gene. Nature 383:819-823.

Mello NK, Mendelson JH, Lukas SE, Gastfriend DR, Teoh SK, Holman BL (1993) Buprenorphine treatment of opiate and cocaine abuse: clinical and preclinical studies. Harv Rev Psychiatry 1:168-183.

Meunier JC, Mollereau C, Toll L, Suaudeau C, Moisand C, Alvinerie P, But- our JL, Guillemot JC, Ferrara P, Monsarrat B, Mazarguil H, Vassart G, Parmentier M, Costentin J (1995) Isolation and structure of the endogenous agonist of opioid receptor-like ORL1 receptor. Nature 377:532-535.

Mogil JS, Pasternak GW (2001) The molecular and behavioral pharmacology of the orphanin FQ/nociceptin peptide and receptor family. Pharmacol Rev 53:381-415.

Mogil JS, Grisel JE, Zhangs G, Belknap JK, Grandy DK (1996) Functional antagonism of mu-, delta- and kappa-opioid antinociception by orphanin FQ. Neurosci Lett 214:131-134.

Mollereau C, Parmentier M, Mailleux P, Butour JL, Moisand C, Chalon P, Caput D, Vassart G, Meunier JC (1994) ORL1, a novel member of the opioid receptor family. Cloning, functional expression and localization. FEBS Lett 341:33-38.

Nishi M, Houtani T, Noda Y, Mamiya T, Sato K, Doi T, Kuno J, Takeshima H, Nukada T, Nabeshima T, Yamashita T, Noda T, Sugimoto T (1997) Unrestrained nociceptive response and disregulation of hearing ability in mice lacking the nociceptin/orphaninFQ receptor. EMBO J 16:1858-1864.

Picard PR, Tramer MR, McQuay HJ, Moore RA (1997) Analgesic efficacy of peripheral opioids (all except intra-articular): a qualitative systematic review of randomised controlled trials. Pain 72:309-318.

Reinscheid RK, Nothacker HP, Bourson A, Ardati A, Henningsen RA, Bunzow JR, Grandy DK, Langen H, Monsma Jr FJ, Civelli O (1995) Orphanin FQ: a neuropeptide that activates an opioidlike $\mathrm{G}$ protein-coupled receptor. Science 270:792-794.

Reynaud M, Petit G, Potard D, Courty P (1998) Six deaths linked to concomitant use of buprenorphine and benzodiazepines. Addiction 93:1385-1392.

Rothman R, Qi NI, Xu H (1995) Buprenorphine: a review of the binding literature. In: Buprenorphine: combating drug abuse with a unique opioid (Lewis J, Cowan A, eds), pp 19-30. New York: Wiley.

Sadee W, Rosenbaum JS, Herz A (1982) Buprenorphine: differential interaction with opiate receptor subtypes in vivo. J Pharmacol Exp Ther 223:157-162.

Takita K, Morimoto Y, Kemmotsu O (2003) Role of nociceptin/orphanin FQ and nociceptin/orphanin FQ peptide receptor in respiratory rhythm generation in the medulla oblongata: an in vitro study. Br J Anaesth 91:385-389.

Tyers MB (1980) A classification of opiate receptors that mediate antinociception in animals. Br J Pharmacol 69:503-512.

Tzschentke TM (2002) Behavioral pharmacology of buprenorphine, with a focus on preclinical models of reward and addiction. Psychopharmacology (Berl) 161:1-16.

Walsh SL, Preston KL, Stitzer ML, Cone EJ, Bigelow GE (1994) Clinical pharmacology of buprenorphine: ceiling effects at high doses. Clin Pharmacol Ther 55:569-580.

Wnendt S, Kruger T, Janocha E, Hildebrandt D, Englberger W (1999) Agonistic effect of buprenorphine in a nociceptin/OFQ receptor-triggered reporter gene assay. Mol Pharmacol 56:334-338. 